\title{
Prevention and Control of Cardiac Arrest in Healthy China
}

\author{
Lei $\mathrm{Hou}^{1,4}$; Yumeng Wang ${ }^{1,2}$; Wenlei Wang ${ }^{3}$
}

\section{Summary}

Cardiac arrest (CA) usually occurs out of hospitals, comprising approximately $50 \%$ of all cardiovascular deaths, which may delay achievement for Healthy China 2030 goals for life expectancy and premature death from major chronic diseases. In this review of Chinese law and health policy, challenges and opportunities are explored for CA prevention and control. A considerable gap would remain even if the CA target in Healthy China 2030 are to be achieved on schedule. Therefore, CA should be included in the national disease prevention and control system and national projects, such as the Healthy Cities Initiative and the Primary Public Health Services to accelerate population-wide Cardiopulmonary Resuscitation training and Automatic External Defibrillation availability. Principles of CA prevention and control should be integrated into all relevant policies.

\section{BACKGROUND}

Cardiac arrest (CA) is a serious clinical condition and the initial symptom in one-fourth of cases of cardiac disease, contributing to approximately $50 \%$ of all cardiovascular deaths worldwide (1-2). CA usually occurs out of hospitals and is often unrecognized in patients with a low risk of cardiovascular disease or who have occult heart disease (2). The rate of emergency medical services (EMS) attending out-ofhospital cardiac arrest (OHCA) varies substantially, from 20.9 per 100,000 people in Singapore to 186.0 per 100,000 people in Rochester, United States. The estimated annual mortality from CA is as high as $4-5$ million deaths worldwide, with 544,000 deaths in China (2-3). An autopsy study showed that only $20 \%$ of sudden cardiac deaths - a common outcome of $\mathrm{CA}$ - were associated with cardiovascular risk factors. Therefore, much about the etiology of CA is unknown, and CA remains unpredictable (4).

One intervention that may reduce mortality from OHCA in non-hospital scenarios is "bystander" cardiopulmonary resuscitation (CPR). However, bystander CPR is underutilized in China, with implementation rates of only $11.4 \%$ in Beijing and $4.2 \%$ in Shanghai, which are much lower than $46.1 \%$ in the United States and $32.2 \%$ in Japan (5). As a result, the success rate of OHCA rescue is as low as less than $1 \%$ in China, compared with approximately $10 \%$ in other developed countries (G).

High incidence of and mortality from CA may delay achievement of the Healthy China 2030 goals on life expectancy and premature mortality from major chronic diseases. Here, the aim of this article is to discuss challenges and opportunities for CA prevention and control by reviewing the laws and health policies related to CA in China.

\section{KEY CONTENTS \& TARGETS}

\section{The Healthy China Initiative (2019-2030),} including two government-driven campaigns related to CA — health literacy and cardiovascular/ cerebrovascular disease prevention and treatment will guide our work over the next 10 years (Table 1). CA-related first aid is the first topic of the Campaign of Cardiovascular and Cerebrovascular Disease Prevention and Treatment, but there is only one quantitative assessment indicator monitored by the government, which is the rate of emergency rescue training among residents, with training of teachers being the primary strategy chosen to achieve improvement of this indicator. In 2020, the Red Cross Society and the Ministry of Education of China issued a joint notice to strengthen CPR training and train teachers specialized in emergency education. The plans involve installing automatic external defibrillations (AED) in crowded places, including schools, workplaces and institutions, airports, transport stations, shopping malls, and cinemas. Organizations involved in implementation of this effort include the National Health Commission, the Ministry of Education, the Ministry of Finance, and the Red Cross Society of China. 
TABLE 1. Campaigns related to cardiac arrest in the Healthy China Initiative (2019-2030).

\begin{tabular}{llll}
\hline \multicolumn{1}{c}{ Campaign } & \multicolumn{2}{c}{$\begin{array}{c}\text { Government-monitored } \\
\text { indicators }\end{array}$} & \multicolumn{1}{c}{ Main practices } \\
\hline $\begin{array}{l}\text { Health literacy } \\
\text { campaign }\end{array}$ & $\begin{array}{l}\text { Mastering basic knowledge } \\
\text { and skills on of first aid } \\
\text { including CPR }\end{array}$ & $\begin{array}{l}\text { Encouraging professional institutions and media to educate the public; } \\
\text { encouraging residents to master essential skills, such as making an emergency } \\
\text { call and CPR; encouraging families to have the first aid kits }\end{array}$ \\
$\begin{array}{l}\text { Cardiovascular and } \\
\text { cerebrovascular } \\
\text { disease prevention and } \\
\text { treatment campaign }\end{array}$ & $\begin{array}{l}\text { Percent of residents with } \\
\text { certification in emergency } \\
\text { rescue training: } \geq 1 \% \text { in } 2022 \\
\text { and } \geq 3 \% \text { in 2030 }\end{array}$ & $\begin{array}{l}\text { Supporting professional institutions to carry out mass emergency rescue } \\
\text { training; training teachers in primary and secondary schools, } 1 \text { teacher trained } \\
\text { for each 50 students in the first aid }\end{array}$ \\
& $\begin{array}{l}\text { Outside the monitored } \\
\text { indicator system }\end{array}$ & $\begin{array}{l}\text { Providing the first aid drugs and AEDs in crowded places; providing an } \\
\text { ambulance for every 50 thousand people; achieving 100\% of 10-second } \\
\text { answering rate for pre-hospital medical emergency institutions; increasing the 5- } \\
\text { minute departure rate of ambulances }\end{array}$ \\
\hline
\end{tabular}

Abbreviations: $C P R=$ cardiopulmonary resuscitation; $A E D=$ automatic external defibrillation.

\section{STRATEGIES}

Timely and effective bystander CPR may be the best hope for survival once CA occurs. Initiating CPR within 1 minute of CA and use of AEDs within 3-5 minutes can increase CA survival rate to $50 \%-70 \%$ (7). Currently, there are four national laws closely related to increase in CA survival (Table 2). Among these, the Civil Code implemented in 2021 is particularly important for legally protecting bystanders who are not medical staff when witnessing a CA and providing onsite first aid. The Primary Healthcare, Medicine, and Health Promotion Law implemented in 2020 guarantees comprehensive measures to improve onsite first aid in terms of training potential bystanders, public participation, availability of equipment, and mechanisms for legal protection. The ongoing Law for Medical Practitioners is anticipated to play a key role in encouraging and protecting medical practitioners to implement a rescue for OHCA by exempting medical practices from restrictions on place, category, and specialty. Lastly, the Law of the Red Cross Society revised in 2017 authorizes the Red Cross Society of China - a non-governmental organization (NGO) - to establish an emergency rescue system in an attempt to improve likelihood of successful rescue from CA.

To supplement national laws, some local governments have enacted detailed regulations to support CA rescue. For example, considering people who are likely to become witnesses of a CA, public transportation drivers and attendants, teachers, tourist guides, firemen, policemen, security staff, and pension service personnel are designated as specific recipients of CPR training in Hunan Province, Shanghai Municipality, Hainan Province, and Nanjing City.
The Regulations of Hunan Province on Spot Rescue stipulates that CPR training should be included in all types of school curriculum. As the availability of AED devices is essential for onsite first aid for CA, the above regulations require or encourage provision of $\mathrm{AEDs}$ in crowded or high-CA-risk places such as transportation hubs, tourist attractions, stadiums, conference and exhibition centers, nursing homes, and schools.

\section{PERSPECTIVE}

Considering that the average response time of prehospital emergency medical services is usually more than 15 minutes in urban areas of China, earlier initiation of high quality bystander CPR and AED use are crucial for saving the lives of OHCA victims $(6,8)$. However, the current $\mathrm{CPR}$ training rate among Chinese residents is less than $1 \%$, much lower than the $33 \%$ reported in the United States and $40 \%$ in France (5). Moreover, the number of AEDs per 100,000 Chinese residents is dramatically lower than that in many industrialized countries $(17.5,13$, and 5 in the developed Chinese cities of Shenzhen, Haikou, and Shanghai, respectively, vs. 700, 276, and as high as 3,399 in the United States, Japan, and in parts of France, respectively) (7). These gaps between China and other industrialized countries must be overcome by developing laws and policies. In particular, the key elements of $\mathrm{CPR}$ training and provision of $\mathrm{AED}$ equipment specified in some local laws should be raised to the level of national laws.

In terms of CPR training, it remains to be determined who should be trained, who should conduct the training, and who should support the training. Health practitioners and people likely to be first to witness CA events are prime candidates for 
TABLE 2. Current national laws closely related to cardiac arrest in China.

\begin{tabular}{|c|c|c|}
\hline Name & Basic description & Function in cardiac arrest \\
\hline $\begin{array}{l}\text { Law for Medical } \\
\text { Practitioners }\end{array}$ & $\begin{array}{l}\text { A draft of this law, issued on } \\
\text { January } 27,2021 \text {, is based on } \\
\text { a revision of a similar } 1999 \text { law }\end{array}$ & $\begin{array}{l}\text { We suggest that medical practitioners should be encouraged and protected to } \\
\text { implement OHCA by exemption from restrictions on their medical practice such as } \\
\text { place, category, and specialty by this law, although this draft includes rescue for } \\
\text { patients in case of emergency. }\end{array}$ \\
\hline Civil Code & $\begin{array}{l}\text { China's first law named after } \\
\text { the code occupies a } \\
\text { fundamental position in the } \\
\text { legal system; implemented on } \\
\text { January } 1,2021\end{array}$ & $\begin{array}{l}\text { Articles } 183 \text { and } 184 \text { provide a basic guarantee of civil rights for any bystander who } \\
\text { conducts out-of-hospital CPR; Article } 1,005 \text { requires organizations or individuals } \\
\text { with legal obligations to fulfill their own rescue duties. }\end{array}$ \\
\hline $\begin{array}{l}\text { Primary Health } \\
\text { Care, Medicine } \\
\text { and Health } \\
\text { Promotion Law }\end{array}$ & $\begin{array}{l}\text { China's first basic and } \\
\text { comprehensive law in the field } \\
\text { of health; implemented on June } \\
1,2020\end{array}$ & $\begin{array}{l}\text { Article } 27 \text { establishes and improves a pre-hospital first aid system, defining what the } \\
\text { jobs of the government as following: 1) carrying out first aid training and public } \\
\text { education; 2) encouraging onsite first aid; 3) providing first aid facilities in public } \\
\text { places; } 4 \text { ) forbidding refusal and delay from first aid centers due to fees. }\end{array}$ \\
\hline $\begin{array}{l}\text { Law of the Red } \\
\text { Cross Society }\end{array}$ & $\begin{array}{l}2017 \text { revised version with } \\
\text { functions of the Red Cross } \\
\text { Society in non-war or non- } \\
\text { armed conflict scenes added. }\end{array}$ & $\begin{array}{l}\text { Article } 11 \text { defines the functions of the Red Cross Society, including establishing an } \\
\text { emergency rescue system, carrying out emergency rescue training, popularizing } \\
\text { emergency rescue and health knowledge, and organizing volunteers to participate in } \\
\text { onsite rescue. }\end{array}$ \\
\hline
\end{tabular}

Abbreviations: $\mathrm{OHCA}=$ out-of-hospital cardiac arrest; $\mathrm{CPR}=$ cardiopulmonary resuscitation.

CPR training. CA training should be considered for inclusion in the national disease prevention and control system, where professional public health institutions such as CDCs can more effectively organize and mobilize the general population. This would not only be responsive to requirements of recent legislation, but also helps offset limitations of the Red Cross Society as an NGO. Establishing permanent professional positions for CPR trainers will help address deficiencies in the availability of training for the public. In terms of AEDs, it is essential to increase the number of AEDs and optimize the placement of AED sites. For example, the local laws noted above suggest many locations for AED sites; however, in communities where the majority of OHCAs occur at home [e.g., $84.7 \%$ and $92 \%$ before and after the COVID-19 pandemic in Lombardy, Italy, respectively (9) ], this may be insufficient, as community-based AED placement does not feature in any of China's laws or policies.

Current CA-related policy measures in the Healthy China Initiative lag behind the law, despite priority being placed on health and prevention in rapidly developing legislation - likely due to the locus of CA prevention and control being largely beyond the reach of the healthcare system. Even if the 2030 Healthy China targets are achieved on schedule, a significant gap with other countries will remain. Therefore, we suggest that CPR training and placement of AEDs be featured in the index systems of the National Healthy Cities, the National Demonstration Areas for the Comprehensive Prevention and Control of Chronic
Diseases, and the National Primary Public Health Services projects. These projects either effectively mobilize government resources or cover a large number of people, which will help to dramatically increase coverage of CPR training and AEDs among the population. Furthermore, in adherence to the principle of including health promotion in all policies, standards for the placement of AEDs should be considered and integrated into all types of building codes, including specifications for construction of civilized cities and beautiful villages to improve AED coverage for CAs.

Since the beginning of the COVID-19 pandemic, $\mathrm{CA}$ cases have increased and the rate of restoration of spontaneous circulation (ROSC) from OHCA has dramatically decreased. This may be because the coronavirus attacks the cardiopulmonary system and because of the strain the pandemic has placed on medical resources. For example, $19.8 \%$ of patients with severe COVID-19 pneumonia experienced an inhospital CA in a single-centered, retrospective, observational study conducted in Wuhan City, Hubei Province; mortality due to CA increased by $58 \%$ in the Lombardy region of Italy; and the ROSC rate dropped to $0.4 \%$ in February 2020 from about $4.5 \%$ before the COVID-19 outbreak in Hangzhou City (9-10). It is therefore urgent to add CA to the monitoring and early warning mechanisms of public health emergencies, required by the Central Committee of the Communist Party of China, in accordance with the principle of "people first and life first."

Conflicts of Interest: No conflicts of interest were reported. 
Funding: Special Foundation for National Science and Technology Basic Research Program of China (2018FY10060002).

doi: $10.46234 / \mathrm{ccdcw} 2021.076$

\# Corresponding author: Lei Hou, houlei@ncncd.chinacdc.cn.

\begin{abstract}
${ }^{1}$ National Center for Chronic and Noncommunicable Disease Control and Prevention, Chinese Center for Disease Control and Prevention, Beijing, China; ${ }^{2}$ Public Health School, Baotou Medical College, Baotou, Inner Mongolia, China; ${ }^{3}$ The Center for Disease Control and Prevention of Xinjiang Uygur Autonomous Region, Urumqi, Xinjiang, China.
\end{abstract}

Submitted: February 02, 2021; Accepted: March 18, 2021

\section{REFERENCES}

1. Krokhaleva Y, Vaseghi M. Update on prevention and treatment of sudden cardiac arrest. Trends Cardiovasc Med 2019;29(7):394 - 400. http://dx.doi.org/10.1016/j.tcm.2018.11.002.

2. Al-Khatib SM, Stevenson WG, Ackerman MJ, Bryant WJ, Callans DJ, Curtis AB, et al. 2017 AHA/ACC/HRS guideline for management of patients with ventricular arrhythmias and the prevention of sudden cardiac death: a report of the american college of cardiology/american heart association task force on clinical practice guidelines and the heart rhythm society. J Am Coll Cardiol 2018;72(14):e91 - e220. http://dx. doi.org/10.1016/j.jacc.2017.10.054.
3. Hua W, Zhang LF, Wu YF, Liu XQ, Guo DS, Zhou HL, et al. Incidence of sudden cardiac death in China: analysis of 4 regional populations. J Am Coll Cardiol 2009;54(12):1110 - 8. http://dx. doi.org/10.1016/j.jacc.2009.06.016.

4. Ifteni P, Barabas B, Gavris C, Moga M, Burtea V, Dracea L, et al. Sudden cardiac death: autopsy findings in 7200 cases between 2001 and 2015. Am J Forensic Med Pathol 2017;38(1):49 - 53. http://dx. doi.org/10.1097/PAF.0000000000000274.

5. Xu F, Zhang Y, Chen YG. Cardiopulmonary resuscitation training in China: current situation and future development. JAMA Cardiol 2017;2(5):469 - 70. http://dx.doi.org/10.1001/jamacardio.2017.0035.

6. Shao F, Li CS, Liang LR, Li D, Ma SK. Outcome of out-of-hospital cardiac arrests in Beijing, China. Resuscitation 2014;85(11):1411 - 7 . http://dx.doi.org/10.1016/j.resuscitation.2014.08.008.

7. Lyv CZ, Zhang H, Chen S, Liu XR, Tian GG, Yan SJ. Expert consensus on layout and delivery of AED in China. Clin J Crit Care Sep, 2020;40(9): 813-9. https://doi.org/10.3969/j.issn.1002-1949. 2020.09.003. (In Chinese).

8. Qi TF, Jing J. Response time of pre-hospital first aid in urban regions in China, 1996-2015: a meta-analysis. Chin J Public Health 2017;33 (10):1466 - 8. http://dx.doi.org/10.11847/zgggws2017-33-10-12. (In Chinese).

9. Shao F, Xu S, Ma XD, Xu ZM, Lyu JY, Ng M, et al. In-hospital cardiac arrest outcomes among patients with COVID-19 pneumonia in Wuhan, China. Resuscitation 2020;151:18 - 23. http://dx.doi.org/10. 1016/j.resuscitation.2020.04.005.

10. Yang FL, Yuan YJ, Song YL, Lu X. The Effect on the out-of-hospital system of patients with out-of-hospital cardiac arrest during the COVID-19 outbreak in one city in China. Ann Emerg Med 2020;76(5):687 - 9. http://dx.doi.org/10.1016/j.annemergmed.2020. 05.032 . 